\title{
LUIZ GAMA: UM POETA E DEFENSOR DOS DIREITOS DOS CATIVOS NO BRASIL OITOCENTISTA
}

\section{LUIZ GAMA: A POET AND DEFENDER OF THE RIGHTS OF THE CATIVES IN OITOCENTIST BRAZIL}

\author{
Tamiris Dorville \\ Jacqueline Lima $^{* *}$ \\ José Geraldo da Rocha ${ }^{* * x}$ \\ Ricardo Marinho ${ }^{* * * x}$
}

\begin{abstract}
RESUMO
Pretende-se neste artigo enaltecer a imagem de Luiz Gonzaga Pinto da Gama, um escritor, Poeta, Jornalista e, principalmente, abolicionista, advogado dos escravos, como ele mesmo se anunciava no principal veículo de comunicação da São Paulo oitocentista e como intitulou e o referenciou o escritor Nelson Câmara em sua obra de mesmo nome, e que segundo Boris Fausto em sua Obra "História Concisa do Brasil", 2014, cita a trajetória histórica de Gama como digna de uma Novela, dado que este, lutou em prol da luta abolicionista com tamanho clamor e fervura. E é desta forma que Luiz Gama é retratado nas demais obras dos poucos historiadores que se atreveram a esmiuçar sua história, assim como narrar essa emocionante história de um homem que sem dúvidas foi um dos responsáveis pela hoje abordada e presente existência da consciência negra, sobretudo no Brasil, país de raízes africanas.
\end{abstract}

Palavras-Chave: Direitos. Abolição. Escravidão. Luiz Gama.

\begin{abstract}
This article intends to praise the image of Luiz Gonzaga Pinto da Gama, a writer, poet, journalist and, mainly, abolitionist, slaves attorney, as he announced himself in the main vehicle of communication from São Paulo nineteenth century and how he referred to the writer Nelson Câmara in his same name work, and according to Boris Fausto in his work "Concise History of Brazil", 2014, quotes the historical path of Gama as worthy of a Novel, since he, fought for the abolitionist fight with so much clamor and fluster. This is how Luiz Gama is portrayed in the other works of the few historians who dared to scrutinize his history, as well as to narrate this exciting story of a man who undoubtedly was one of the responsible for the nowaday approach and present existence of black conscience, especially in Brazil, a country with African roots.
\end{abstract}

Keywords: Rights. Abolition. Slavery. Luiz Gama.

\footnotetext{
*Graduação em História, pela UNIGRANRIO.

** Professora do PPGHCA/UNIGRANRIO. Pós-Doutorado em História. Doutorado em Sociologia. Mestrado e Graduação em História.

${ }^{* * *}$ Professor do PPGHCA/UNIGRANRIO. Doutorado, Mestrado e Graduação em Teologia.

***** Professor do Curso de História da UNIGRANRIO. Doutorado em Ciências Sociais. Mestre em Sociologia e Graduação em História.
} 


\section{INTRODUÇÃO}

O presente artigo resulta de uma pesquisa, cujo objeto de estudo e análise foi o papel de um homem negro que viveu no século XIX atuando à favor da causa abolicionista, em contraponto à visão eurocêntrica da História que enaltece apenas seus personagens brancos, europeus, e nobres, como é o caso da Historiografia didática que simboliza tão somente a Princesa Isabel como precursora do Abolicionismo no Brasil, ao passo que aqueles que mais lutaram dentre as demais insurreições junto aos africanos escravizados, foram esquecidos e relegados no processo histórico e na cotidianidade do processo educacional nas escolas brasileiras. Haja vista, a história oficial contada sobre Zumbi dos Palmares, aquele que era caracterizado por ser um homem forte, escravo rebelde, andava descalço e maltrapilho. Esta é até hoje a construção da imagem da gente negra na História. Uma visão que menospreza, que a coloca como gente negativa e inferior, razão pela qual se torna importante tentarmos com discussões dedicadas em pesquisas como a presente, o enaltecimento dos heróis negros, assim como se enaltecem os heróis europeus brancos, nobres e portadores de um escudo, uma espada e uma coroa.

Assim, esta pesquisa tratará de abordar a história de um grande homem, filho de uma negra africana livre e de um fidalgo, do qual na infância, o vendera como escravo. Este menino cresceu e se tornou um homem escritor, poeta e jornalista, advogado, abolicionista e defensor dos direitos dos negros. Anos após sua morte ganhou da $\mathrm{OAB}$ - Ordem dos Advogados do Brasil, o registro de advogado na mesma Instituição, em função de sua atuação que propiciou a libertação a mais de 500 negros africanos escravizados no Brasil do Século XIX. À luz dos Direitos Humanos, dar visibilidade a essa prensagem de nossa história é trazer para a pauta do dia a relevância de sua luta bem como inscrever as lutas de promoção de igualdade racial no cenário dos Direitos Humanos.

Sobre a ideia de nacionalidade Eric Hobsbawm (1990) observa que até 1880 não havia uma preocupação teórica com elementos constitutivos de uma nação, língua, religião, etnia, ainda não representavam em importância, os debates alicerçados a tais questões. A partir desta data as ideias de raça e nação começam a se confundir e dar base a algumas discussões no cenário que se anunciava.
O autor alerta para o como devemos pensar a nação calcada em objetivismos e subjetivismos, sendo estes ambíguos. Para se definir um caráter objetivo de uma nação é preciso um caráter subjetivo, ou seja, a tentativa de se definir a nação pela consciência de pertencimentos, corroborando com outros autores, dentre eles, Benedict Anderson (2008).

A necessidade de se fomentar uma identidade nacional em fins dos 1800 no Brasil foi, também o comprometimento de intelectuais brasileiros em se aproximar dos ideais das nações europeias. Mas, as resistências, de se pensar um Brasil alicerçado em componentes nacionais aparecem em alguns homens. É o que vermos neste artigo.

\section{A RELEVÂNCIA E A NECESSIDADE DE FALAR SOBRE LUIZ GAMA}

Desde já, é necessário aclamar o nome de Gama, e é esta tarefa que os demais historiadores e escritores que o fizeram se preocuparam ao tecer a trajetória de Luiz Gonzaga Pinto da Gama na Historiografia do Brasil, sobretudo, no século XIX, período em que esteve o movimento abolicionista cada vez mais encurtando a escravidão no Brasil.

O que sempre se propôs buscar ao falar do personagem em questão, é a erradicação da questão do preconceito, do racismo, em um país que possui em seu âmago o sangue africano, mas que, contudo, se manteve até hoje, mesmo que de uma maneira disfarçada, numa lógica de supremacia branca.

Luiz Gama a seu tempo lutou contra a política de embranquecimento eurocêntrico na sociedade escravocrata oitocentista, e essa luta a favor da abolição, num país como o Brasil, marcado pelo preconceito nas diversas áreas da sociedade, é necessária e imprescindível ser contada e aclamada, enaltecida, a fim de que dessa forma se possa alcançar a erradicação, mesmo que progressivamente e gradualmente, do menosprezo do negro no Brasil. E essa foi a principal finalidade de Luiz Gama com sua luta a favor do abolicionismo, o orgulho negro.

Elciene Azevedo (1999), destaca um trecho da obra de Luiz Silva (1989), onde o autor diz:

Afeto e exemplo revolucionário sendo aliados ao lado materno (negro) e a ignomínia do lado paterno (branco), num contexto em que este último acabou por se aliar ao significado de repressão, violência 
e poder, constituem a plataforma psíquica para a consciência desenvolvida pelo "Precursor do Abolicionismo. (Silva, Luiz: Luiz Gama: uma trajetória além de seu tempo. Estudos Afro-Asiáticos, n. 16, mar., 1989, p. 61).

Elciene Azevedo revela em sua obra em questão, através de sua interpretação a respeito da outrora citada obra de Luiz Silva:

A personalidade que o autor confere a Luiz Gama é, portanto, forjada na oposição entre o negro e o branco. A cor negra representaria para ele a admiração votada a sua mãe - uma negra africana revolucionária; já a cor branca estaria intimamente ligada à mágoa alimentada pelo pai por tê-lo vendido como escravo. Este dualismo teria deixado para Luiz Gama apenas uma saída: identificar-se com a mãe e afirmar-se como negro. É dentro deste universo polarizado, de negros versus brancos, que o personagem de Luiz Gama é contextualizado. Segundo o autor embora ele tivesse sido instruído conforme um padrão de educação eurocêntrico, seria possível encontrar em suas poesias elementos da tradição oral negra, além de uma inversão satírica de valores europeus. A sátira assim se transformaria em uma importante arma contra o embranquecimento e, principalmente, na valorização do "Ser Negro." (AZEVEDO, 1999: p. 27).

Elciene Azevedo, nos explica que Luiz Gama e sua luta tiveram raízes originadas na identificação de Gama pela trajetória revolucionária de sua mãe Luiza Mahin, da qual fora uma negra africana livre que deixou seu lar para lutar junto a seus semelhantes cativos na Revolta dos Malês, uma das principais insurreições antiescravagistas da Bahia em 1835. ${ }^{1}$ E quanto ao pai de Gama, nosso personagem se alimentava de sua mágoa por ter sido vendido como cativo por seu genitor, e lutava contra esse menosprezo e injustiça dos brancos sobre os negros, fazendo uma verdadeira e significante marca no propósito abolicionista já a seu tempo.

De acordo com Luiz Silva (1989), Gama já a seu tempo se utilizava da sátira como arma para lutar a favor do antiescravismo. E assim, o fez, de maneira argumentativa, quando se valia de advogado em

\footnotetext{
${ }^{1}$ Revolta dos Malês foi um levante promovido por escravos, entre eles, muçulmanos. O motim ocorreu na cidade de Salvador - BA, entre os dias 24 e 25 de janeiro de 1835 (no fim do mês sagrado do Ramadã), há exatos 180 anos. Cf. João José Reis. Rebelião escrava no Brasil: a história do Levante dos Malês (1835). São Paulo: Companhia das Letras, 2003.
}

defesa dos cativos que o procuravam em busca de conquistar alforria, seja através de veículos intelectuais através da literatura, como o fez em sua obra de 1859, "Trovas burlescas de Getulino", onde através de o pseudônimo de Getulino, Gama tecia críticas denunciativas à sociedade escravocrata do Brasil do século XIX, e bem como, de maneira radical, como o escritor Sud Mennucci o retrata, em sua obra de 1938, "O Precursor do Abolicionismo no Brasil", seja na luta através da argumentação jurídica aflorada pela qual seu conhecimento adquirido pela sua curiosidade pelo direito o proporcionou a agir na defesa dos cativos.

Portanto, seja retratado como radical por Mennucci, ou como um poeta engajado por Luiz Silva, Gama é sempre destacado como figura exaltante e característica no processo abolicionista brasileiro, e sua relevância foi tamanha que se não fosse a ainda existente, mesmo que disfarçada, como dito anteriormente, supremacia branca no Brasil, Luiz Gama poderia ter sua imagem ressaltada no 13 de maio de 1888 , no lugar da Princesa Isabel, branca e nobre, pois sem desmerecer sua importância ao assinar a Lei Áurea que abolia de vez a escravidão no Brasil, Gama foi sem dúvidas o personagem ávido que lutou com tamanha fervura e enfrentou dificilmente barreiras e obstáculos em favor da abolição da escravatura brasileira.

Tanto Luiz Silva, quanto Elciene Azevedo, quando interpretam a visão desse autor sobre Gama, contam como o poeta abolicionista tratou de introduzir a seu tempo uma noção do negro como um ser, indivíduo, diferentemente da sociedade oitocentista brasileira tomada pela supremacia branca, que os tratava não como cidadãos, mas como coisas, mercadorias.

Luiz Gama trouxe com sua luta e defesa dos seus, uma noção de orgulho negro. Mesmo naquele momento onde para os negros só restava serem submissos ao eurocentrismo branco e submergirem em total melancolia de viverem numa sociedade onde eram escravizados, maltratados, humilhados e menosprezados, tão somente por terem nascidos com a pele escura.

Num tempo atual onde mesmo depois de tanto enfrentamento ao preconceito e ao racismo, nomes como o de Luiz Gama precisam ser exaltados a fim de que de alguma forma o negro possa ser visto como figura de valor e heroica, pois o personagem do qual este artigo está a tratar simplesmente configurou na história brasileira heroísmo, garra e luta pelo ideal 
abolicionista e dessa forma, falar sobre Gama e sua trajetória é afirmar o negro não só como rebelde, subversivo e menosprezado, mas sim como uma figura que se valeu de poesias, atitudes não submissas, argumentações jurídicas, jornalismo e fé, para configurar o enaltecimento do negro.

Um mundo em que pouco se vê figuras negras em ambientes valorizados, seja nas universidades, seja em cenários do ramo profissional, ou em qualquer outro setor da sociedade onde apenas se elevam figuras brancas, é de suma importância destacar Luiz Gama como símbolo pertencente a causa negra, pois assim, é que se torna possível erradicar o preconceito racial, enaltecendo e valorizando como herói da história brasileira um negro, quando tão somente a sociedade está acostumada a ver enaltecidos apenas heróis brancos.

A partir do momento em que o negro, oprimido pela supremacia branca, descobre a relevância de um personagem heroico que lutou pela erradicação da escravidão, contra a prepotência branca sobre os negros, nasce um sentimento de afirmação do "ser negro", do orgulho como um indivíduo negro, onde até então é desfalcado pela imagem deste na história pela visão de rebeldia, subversão, sendo maltrapilho e descalço, como a exemplo da figura histórica de Zumbi de Palmares.

Com Luiz Gama sendo cada vez mais reconhecido no mundo acadêmico e literário, se torna possível o maior alcance da valorização negra perante a sociedade que ainda persiste em fazer imperar o preconceito racial espalhado pelo sentimento de superioridade do eurocentrismo branco para com os negros.

A despeito da problematização que se faz em relação ao mundo negro sendo visto como inferior perante a sociedade, há relatos exemplificativos sobre fatores consideráveis dessa supremacia branca, sobretudo europeia, que não só se derramou sobre os negros, mas também sobre os nativos, quaisquer povos que fossem caracterizados por serem diferentes dos costumes europeus, cujo eram vistos por estes como não civilizados, sejam por não corresponderem do mesmo tom de pele, pela mesma aparência.

Como aponta Lilia Schwarcz em sua obra: Nem preto, nem branco, muito pelo contrário: Cor e raça na sociabilidade brasileira,

Afinal, desde que o Brazil é Brasil, ou melhor, quando era ainda uma América portuguesa, o tema da cor nos distinguiu. Os primeiros viajantes destacavam sempre a existência de uma natureza paradisíaca, mas lamentavam a "estranheza de nossas gentes." (SHWARCZ, 2012: p. 11).

A autora em tela conseguiu a partir de sua obra em questão nos trazer a reflexão dos fatores pelos quais é imperante no mundo a supremacia branca, sobretudo sob eurocêntrica, ademais com relação ao crescente desenrolar da historiografia retratando os povos não europeus como não civilizados, como seres inferiores ao conceito do branco europeu como o belo e perfeito.

Lilia Shwarcz (2012), escreve sobre o conto "a princesa negrina", de Cecília Bandeira de Mello Rebelo de Vasconcelos - Madame Chrysantheme, publicado no Brasil em 1912 e na Inglaterra em 1937, cuja obra retrata um casal de majestades que desejava ter uma filha, depois de anos de matrimônio e uma fada madrinha os concedia um desejo. A rainha então disse a fada que "gostaria de ter uma filha, "mesmo" que fosse escura como a noite que reina lá fora." A fada concedeu o desejo de modo literal e deu ao casal uma filha negra. Tal fato causou tamanha comoção ao reino, que a fada prometeu que se a menina se isolasse no castelo até os dezesseis anos, esta se tornaria branca. Porém, se desobedecessem tal promessa, esta não se realizaria e o futuro da menina não seria só negro na cor. Assim, a menina tentada por uma serpente, que a convida para sair pelo mundo, deixa o castelo e conhece horror e traição. Para salvar-se, concorda em casar-se com o "animal mais asqueroso que existe sobre a Terra" - o odioso Urubucaru." Ao desfecho da história, a menina aos prantos na sua noite de núpcias, lamentava não ter casado com seu deformoso marido, mas por não ter se tornado branca, e diante de suas lamúrias vê seu marido se transformar num príncipe diamante, um belo e jovem nobre, enquanto ela se transformou na mais bela alva jovem. De acordo com a análise da autora, sobre o contexto do então "conto para crianças":

Rosa negra viu seus braços envolverem o mais belo e nobre jovem que já se pôde imaginar, e Urubucaru, agora o príncipe Diamante, tinha os meigos olhos fixos sobre a mais alva princesa que jamais se vira." Final da história: belo e branco, o casal conheceu para sempre "a real felicidade". Dizem que "quem conta um conto aumenta um ponto." Se o dito é verdadeiro, a insistência na ideia de branqueamento, o suposto de que quanto mais branco melhor, 
fala não apenas de um acaso ou de uma ingênua coincidência em uma narrativa infantil, mas de uma série de valores dispersos na nossa sociedade e presentes nos espaços pretensamente mais impróprios. A cor branca, poucas vezes explicitada, é sempre uma alusão, quase uma bênção; um símbolo dos mais operantes e significativos, até os dias de hoje. (SHWARCZ 2012: p. 11).

A autora propõe com a análise do conto da "Princesa negrinha," entender os fatores preponderantes para a questão racial em nossa sociedade, sobretudo para o caráter do embranquecimento, principal argumento de valorização da supremacia branca europeia sobre os povos não civilizados.

Estava presente na literatura, nas cartas, nas relações interpessoais e coletivas a noção do conceito do ser branco como fator superior sobre, a supremacia branca.

Ainda assim, o próprio imperador D. Pedro II fomentou políticas de embranquecimento no Brasil quando através da imigração de europeus para mão-de-obra, buscava erradicar a população negra aqui, e fazer-se então uma nação americana de povos europeus, brancos, como é narrado na obra: "O advogado e o Imperador” de Gilberto de Abreu Sodré Carvalho:

Já Dom Pedro II representava o passado, acreditava no escravismo como um "mal necessário". O imperador tinha a clara intenção de "branquear" a população brasileira. (...) Dom Pedro II acreditava que trazer imigrantes europeus, brancos com certeza, seria uma estratégia de governo para ajudar a dizimar a população negra analfabeta e desassistida, que estaria ainda mais fragilizada após a inevitável abolição da escravatura, exigida pelos britânicos e pelo mundo civilizado em geral. Para o imperador, branquear a população faria o Brasil se parecer com as nações europeias, com os povos civilizados, e isso era urgente para o crescimento do país e o reconhecimento de nossa viabilidade como país igual aos demais. Os brancos vindos da Europa substituiriam, com vantagem, os negros brasileiros como mão de obra. E estes sucumbiriam com o tempo. (CARVALHO, 1947).

A partir da nota de apresentação do romance histórico de Gilberto de Abreu Sodré Carvalho, em que é citado o objetivo de branqueamento do Imperador em pleno século XIX, é que podemos observar claramente os fatores que pode-se citar como determinantes para a expansão do sentimento de desvalorização do negro pela superioridade do enaltecimento branco sobre os demais.
O eurocentrismo da supremacia branca esteve e está ainda presente na nossa sociedade, e precisa ser combatido e tão somente discutido, aceita a sua existência acima de tudo, para que com isso, se possa de uma vez erradicar a discriminação e o preconceito e elevar a autoestima do orgulho do ser negro, valorizar e enaltece-lo a fim de que dessa forma possa-se alcançar o verdadeiro sentido de fraternidade e igualdade que é tão aclamada pela humanidade, mas que a superioridade e supremacia sobre os demais, acaba afastando esse ideal e o transformando no horror pregado pelas diferenças.

Luiz Gama, lutou tão somente pela injustiça da sociedade escravocrata naquele momento, mas sem abandonar o seu sentimento de orgulho do "ser negro", por mais que tenha precisado se valer de instrumentos do mundo branco como a imprensa e a advocacia para ir em busca do seu ideal abolicionista.

A questão racial é a principal motivação a ser posicionada e relevada neste artigo, através da discussão da relevância de Gama e da colocação desse personagem histórico ao patamar de heroí da causa abolicionista, da mesma forma como ele sempre é retratado quando poucos que se mantiveram a narrar sua trajetória o fizeram, com destreza, emoção e paixão, a fim de enaltecer a imagem do ser negro, daquele que lutou com orgulho de sua cor e de quem o era, que adentrou no mundo branco sem abandonar sua origem e seu ideal de justiça para com aqueles que ainda sentiam na pele o peso da injustiça da sociedade escravagista.

\section{UM POUCO DA TRAJETÓRIA DE LUIZ GAMA}

Filho de uma africana livre, que viera da Costa da Mina da África, era na nação nagô, Luiza Mahin, e de um fidalgo português. Aos dias 21 de junho de 1830, em um sobrado em Salvador, nascia Luiz Gonzaga Pinto da Gama.

A trajetória de Luiz Gama que se conhece provém de sua Carta à Lúcio de Mendonça (Fundador da Academia Brasileira de Letras), de 25 de Julho de $1880,{ }^{2}$ e a partir deste manuscrito que é praticamente

\footnotetext{
${ }^{2}$ Carta de Luiz Gama à Lúcio de Mendonça, São Paulo, 25 de Jul. 1880, Biblioteca Nacional/Manuscritos: Correspondência avulsa. Sud Mennucci, O precursor do abolicionismo no Brasil. Luiz Gama, São Paulo, Nacional, 1938, p. 19-26.
} 
uma autobiografia de Gama, é que pode-se conhecer sua história.

De acordo com a carta, Luiza Mahin era livre, e era perseguida e envolta em insurreições africanas, sobretudo a já então mencionada anteriormente, Revolta dos Malês. O pai de Gama, em 10 de novembro de 1840, o vendeu como escravo para quitar dívidas de jogo.

Luiz Gama, com 10 anos de idade, embarcou em um navio do tráfico negreiro, o chamado Patacho Saraiva, e chegou primeiramente ao Rio de Janeiro, cujo era um lugar com alto índice de comercialização de escravos, e lá, Gama foi deixado na Candelária, onde foi parar na casa de um português que administrava uma casa de velas e vendia escravos.

De acordo com a Carta de Gama a Lúcio de Mendonça, 1880, Gama menciona ter saído da casa dos Vieira em prantos, tendo em vista ter sido tão afeiçoado por suas filhas e por uma mucama que o cuidou durante os dias que ali permaneceu.

Luiz Gama foi vendido a um alferes paulistano chamado Antonio Pereira Cardoso, que comercializava cativos, e Gama seguiu com ele para São Paulo.

Já em São Paulo, foi rejeitado por compradores, pois ao terem conhecimento de que era baiano, o rejeitaram. Naquele momento, de inúmeras insurreições de escravos na Bahia, as notícias corriam e os senhores ficavam apreensivos e temerosos de adquirirem escravos provenientes da Bahia, com medo de rebeliões e revoltas. Foi assim com Luiz Gama, como aponta Elciene Azevedo, 1999:

Para o alferes Cardoso, no entanto, talvez este negócio não tenha sido tão bom quanto foi para o português. Ao fim da cansativa aventura pelo interior paulista, retornou para sua casa na capital da Província com dois "refugos", rejeitados pelos compradores, como se rejeitam "coisas ruins", por serem escravos baianos. Por aqueles tempos, escravos vindos da Bahia eram vistos com temor por alguns senhores das províncias do sul e sudeste do Império. Acostumados a ouvir histórias sobre insurreições por aquelas bandas, tinham os escravos dessa região como ameaçadores da paz das senzalas, e consequentemente da tranquilidade da casa grande. (AZEVEDO, 1999: p. 38).

Nesse contexto, Gama fica na Casa dos Cardoso, e lá serve com práticas de trabalhos domésticos, além de aprender também o ofício de sapateiro com o escravo José, cujo estava ao acompanhá-lo, quando também fora recusado junto a Gama pelos compradores de escravos.

Luiz Gama, aprendeu a lavar, engomar e costurar, porém, este menino autodidata não se manteve apenas ao aprendizado das questões de cunho doméstico, pois durante a estadia de um hóspede de nome Antônio Rodrigues, que havia se hospedado na casa dos Cardoso para estudar, Gama aos dezessete anos de idade, aprendeu a escrever com Rodrigues, que virou seu amigo.

A partir daí, Gama fugiu no ano seguinte, em 1848, e de acordo com o próprio em auto narração em sua carta, obteve provas concretas de sua liberdade, o que o fez fugir da casa do Alferes Antonio Pereira Cardoso, cujo este de acordo com Gama o votava elevada estima.

O que se sabe a partir da Carta, 1880, é que Gama se assentou como Praça. Serviu até o período de 1854, onde teve baixa de serviço por suposta insubordinação por ter ameaçado a um oficial que o tivera insultado. Luiz Gama ficou detido por 39 dias, de 01 de julho a 09 de agosto daquele mesmo ano.

No período em que esteve como praça da Força Pública de São Paulo, Luiz Gama também desempenhou atividades de escrita como copista do escrivão Benedito Antonio Coelho Neto, e também como amanuense, aquele que escreve textos à mãe, copista, escrevente, secretário, do gabinete do delegado de polícia Francisco Maria de Souza Furtado de Mendonça, como Gama aponta em trecho de sua Carta:

Durante o meu tempo de praça, nas horas vagas, fiz-me copista; escrevia para o escritório do escrivão major Benedito Antonio Coelho Neto, que tornou-se meu amigo; e que hoje, pelo seu merecimento, desempenha o cargo de oficial-maior da Secretaria do Governo; e, como amanuense, no gabinete do excelentíssimo Sr. Conselheiro Francisco Maria de Souza Furtado de Mendonça, que aqui exerceu, por muitos anos, com aplausos e admiração do público em geral, altos cargos na administração, polícia e judicatura, e que é catedrático da Faculdade de Direito, fui eu seu ordenança; por meu caráter, por minha atividade e por meu comportamento, conquistei a sua estima e a sua proteção; e as boas lições de letras e de civismo, que conservo com orgulho. (Carta de Luiz Gama à Lúcio de Mendonça, 1880).

Durante a estadia na prisão, o personagem deste artigo aponta, em sua carta tratada como autobiográfica 
por estudiosos, que passava as noites lendo e os dias em total insônia, e quase sempre pensava em sua mãe e sua memória.

A partir deste relato, é de se supor que toda a garra e luta de Gama pelo ideal abolicionista foi raiz da memória revolucionária de sua mãe Luíza Mahin tão quanto sua vivência sendo vendido e tratado como escravo, e seus artifícios para tal luta possuem raiz na vivência de suas relações com figuras do mundo branco, sobretudo intelectual.

Em 1856 até 1868 serviu como amanuense, sendo demitido por insubordinação, como o mesmo relata:

Em 1856, depois de haver servido como escrivão perante diversas autoridades policiais, fui nomeado amanuense da Secretaria de Polícia, onde servi até 1868, época em que "por turbulento e sedicioso" fui demitido a "bem do serviço público", pelos conservadores, que então haviam subido ao poder. A portaria de demissão foi lavrada pelo dr. Antonio Manuel dos Reis, meu particular amigo, então secretário da polícia, e assinada pelo exmo. dr. Vicente Ferreira da Silva Bueno, que, por este e outros atos semelhantes, foi nomeado desembargador da relação da Corte. (Carta de Luiz Gama à Lúcio de Mendonça, 1880).

A Despeito desse episódio em que Gama é demitido de seu cargo no serviço público paulista, sabe-se que Luiz Gama, se valendo dos seus conhecimentos no mundo letrado e da imprensa, do mundo nobre do poderio branco, sendo estimado por diversas figuras de autoridade, e sobretudo do mundo das letras e do direito, o poeta adquiriu notáveis conhecimentos não só na escrita como no âmbito jurídico, por suas relações de convívio até mesmo com o conselheiro Francisco Maria de Sousa Furtado de Mendonça, que era além de chefe de polícia, professor da faculdade de direito, que de acordo com Gama o proporcionou estas lições, e o encorajou na personificação de "advogado dos escravos" na defesa destes.

Como aponta Elciene Azevedo, 1999, Luiz Gama foi demitido de seu cargo de amanuense, por ter supostamente desacatado um juiz municipal através de uma reiteração a um despacho do juiz sobre o processo de um escravo que estava a lutar por alforria através da defesa de Gama, pelo qual foi um dos demais escravos a bater à porta de Gama em busca de justiça.

Nas palavras da autora, o escravo, de nome Jacinto, "alegava que seu cativeiro era ilegal, pois havia chegado ao Brasil após a lei de 07 de novembro de 1831, que proibira o tráfico negreiro." O juiz do caso anunciou em seu despacho que o escravo deveria abrir processo em lugar de domicílio do seu senhor, e em contrapartida, Luiz gama em resposta disse-lhe ao juiz que seu despacho era ofensivo da lei e que Vossa Excelência deveria cumprir o seu dever. O juiz então enfurecido resolveu processar Gama, que mobilizou poderosos da autoridade a proceder a demissão de Gama. Em resposta ao jornal da Capital, Gama diz sobre sua demissão:

"Honro-me com a demissão que acabo de receber [...]" Explicava em seguida que o seu crime fora defender Jacinto e outros negros ilegalmente escravizados contra a senha senhorial e a chicana jurídica. (AZEVEDO, 1999: p. 16).

Percebe-se pela forma como Gama colocava seus argumentos perante as poderosas e arbitrárias decisões judiciais com relação à sua demissão do seu ponto de vista injusta, que ele se mantinha firme, relutante e com tamanha garra ao dizer que a motivação para tal ato, fora simplesmente sua luta no cumprimento da lei que o magistrado se recusou a fazer-se cumprir.

Ainda sobre o episódio de sua demissão, Gama deixa claro em sua Carta, 1880, que sua demissão resultou de sua prática pelo "bem do serviço público", o que fundamenta sua luta como advogado na defesa pela alforria dos negros escravizados ilegalmente:

Em 1856, depois de haver servido como escrivão perante diversas autoridades policiais, fui nomeado amanuense da Secretaria de Polícia, onde servi até 1868, época em que "por turbulento e sedicioso" fui demitido a "bem do serviço público", pelos conservadores, que então haviam subido ao poder. A portaria de demissão foi lavrada pelo dr. Antonio Manuel dos Reis, meu particular amigo, então secretário da polícia, e assinada pelo exmo. dr. Vicente Ferreira da Silva Bueno, que, por este e outros atos semelhantes, foi nomeado desembargador da relação da Corte. (Carta de Luiz Gama à Lúcio de Mendonça, 1880).

Assim como defendia a causa pela liberdade dos negros, Gama também mantinha em sua casa, dinheiro guardado para a compra da alforria de negros que batiam à sua porta clamando por liberdade.

Luiz Gama se anunciava em jornais paulistas como disposto a defender qualquer escravo colocado nesta condição ilegalmente, como comprovado neste anúncio abaixo extraído do acervo do jornal Correio Paulistano de 23 de janeiro de 1870, Edição 4074: 


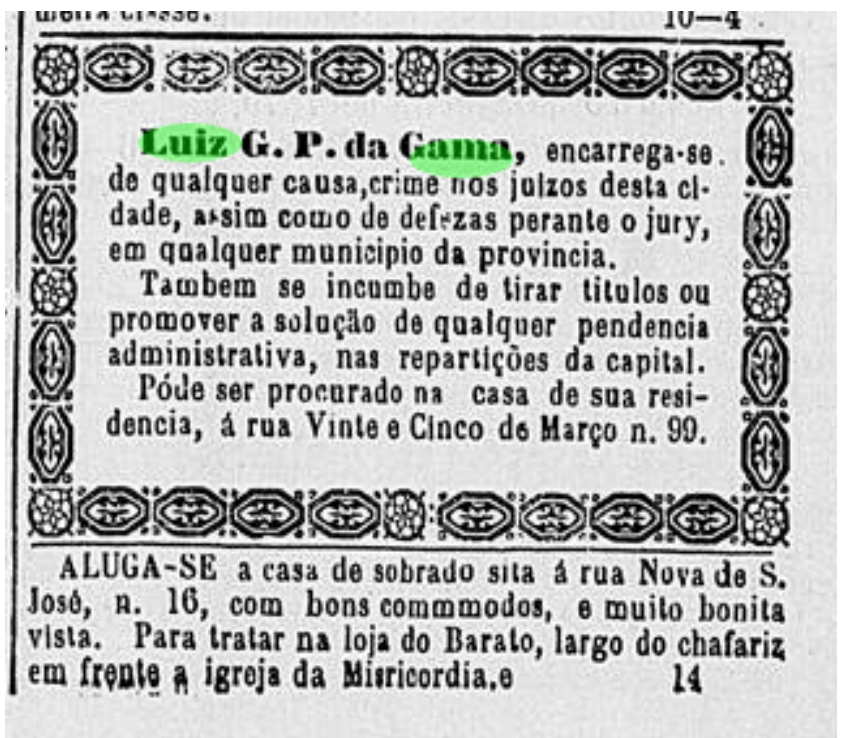

A luta abolicionista de Luiz Gama não se manteve apenas na área jurídica e na área jornalística, onde também publicou seus escritos, como o mesmo menciona na sua aclamada carta, mas também na literatura como em 1859, publicara através do pseudônimo Getulino, a obra "Trovas Burlescas, onde denunciava de forma satírica a sociedade escravocrata oitocentista e dando real significado ao romantismo brasileiro com suas poesias.

Assim como a obra em tela, Gama fundou e escreveu para o jornal Diabo Coxo, o primeiro jornal satírico a ser fundado no século XIX, e dentre seus escritos, contribuiu com seus versos satíricos enaltecendo a alma negra, a beleza de ser negro.

Um de seus poemas que podem exemplificar essa valorização, foi publicado no jornal outrora citado, e teve por fim exaltar e privilegiar a beleza negra, se chama meus amores:

Meus amores são lindos, cor da noite

Recamada de estrelas rutilantes;

São formosa ceroula, ou Thetis negra,

Tem por olhos dois astros cintilantes.

Em rubentes granadas embutidas

Tem por dentes as pérolas mimosas,

Gotas de orvalho que o inverno gela

Nas breves pétalas de carmínea rosa.

O colo de veludo Vênus bela

Trocara pelo seu, de inveja morta;
Da cintura nos quebros há luxúria

Que a filha de Cyneras não suporta.

Quando a brisa veloz, por entre anáguas,

Espaneja as cambrais escondidas,

Deixando ver aos olhos cobiçosos,

As lisas pernas de ébano luzidas.

Santo embora, o mortal que a encontra para;

Da cabeça lhe foge o bento siso;

Nervosa comoção as bragas rompe-lhe

E fica como Adão no Paraíso.

Dar cultos à beleza, amor aos peitos,

Sem vida que transponha a eternidade,

Bem mostra que a sandice estava em voga

Quando Uranus gerou a humanidade.

Mas que o fado eníquo não consente,

Que amor, além de campa, faça vasa,

Ornemos de cupido as santas aras,

Tu feita em fogareiro, eu feito em brasa.

(GAMA, 1865: p. 160).

É clara a observância de que numa época marcada pelo escravismo e pela violência, sobretudo com a mulher negra que se pode ter conhecimento pela historiografia a respeito do tema, que Gama através desse significativo poema, teve por fim enaltecer e valorizar a beleza negra e desta forma também estaria lutando contra a injustiça do menosprezo negro sustentado pela escravidão.

\section{CONSIDERAÇÕES FINAIS}

Articulado ao papel da "história vista de baixo", podemos entender que o lugar dos negros no Brasil, a fim de reconhecimento como algo a ser estudado esteve relacionado a leis, como o caso da 10.639. A possibilidade do estudo de uma perspectiva da História Social se estabelece quando é dada a chance do aluno conhecer e até mesmo reconhecer-se na própria história.

Dito isto, não só a importância de leis, mas a forma como o Ensino de História é conduzido, devem garantir no ensino-aprendizagem, o trato à diversidade, o enriquecimento cultural, a investigação, para que 
haja uma coerência entre o que é ensinado e o que é apreendido. Estamos aqui, falando de valores.

Embora haja uma diretriz que reconheça as especificidades das áreas, algumas exigências para os docentes acabam contemplando algo já dimensionado pela perspectiva do Ensino de História, já que são característicos do pensamento crítico e orientador das humanidades. Deste modo, o trabalho interdisciplinar vem muito a contribuir para uma articulação de formação comum, fazendo o professor e aluno refletirem sobre a consciência da ação educativa, a ponto de se entender que a História não é só feita dos grandes himens considerados brancos/europeus/de alto poder aquisitivo.

Saviani (1997) indica que diferente do que se pensa, o homem adaptou a natureza a sua forma de educação e historicamente esta educação foi construída por etapas na história mundial e na do Brasil. E no Brasil, embora as propostas tenham sido postas desde cedo, como por exemplo, o ensino laico, somente no período republicano isso foi alcançado e a educação popular se coloca como um problema nacional ainda hoje.

A Constituição de 1946 ao elaborar uma possibilidade de um sistema nacional de educação, pensado como um direito de todos e um ensino primário como obrigatório, tenta entender a educação como um instrumento democrático. Porém, até os anos 1970, o ensino profissional discutido na Lei de Diretrizes e Bases 5692/71 marcou um ensino voltados às elites e a tentativa de um ensino público, nacional e democrático, não foi alcançado e continuou sendo discutido na LDB 9394/96.

Para além das leis, enquanto no século XIX o que predominava era uma história política a partir dos estudos destes grandes homens e grandes fatos, a escola legitimava a ideia do cidadão, da nação e da pátria, enquanto silenciava outras gentes e outros assuntos. E, embora nos anos 1930, já se tenha um grande salto de uma história crítica no Brasil, Elza Nadai (1993) faz lembrar que somente nos anos de 1960 o encontro da História com demais disciplinas a torna mais problematizadora.

Mudavam os objetos, as fontes, os olhares, sendo controlados durante o período da Ditadura Militar (1964-1985). Atualmente, já podemos dizer que há uma discussão desde os anos 90 do século XX de questões primordiais de que, por exemplo, o saber escolar é voltado para um poder. Mas, também se compreende que essa História pode estar vinculada à micro-histórias, que ela depende de um método e que professores e alunos devem ser encarados como agentes históricos e que devem se utilizar de fontes cada vez mais diversificadas. (CUNHA, 2000).

Nesta mesma história de luta dos negros no Brasil, muitos dos seus verdadeiros heróis caíram na invisibilidade em função de uma história contada à luz dos interesses dos vencedores, consequentemente, suas contribuições foram esquecidas. O poeta, Luiz Gama, se inscreve nessa história que precisa ser recontada. Ele contribuiu de forma louvável para a exaltação e valorização da consciência negra no Brasil, pois com seu conhecimento de um autodidata, se valeu da literatura, da imprensa, do meio jurídico, para a defesa dos direitos dos negros diante de uma sociedade marcada pela escravidão e pelo menosprezo sobre o negro. Contudo, não se limitou tão somente a estes âmbitos, como também atuou na causa republicana, esta que como a saber na historiografia brasileira, era a favor da abolição por ser contra os interesses monárquicos. Também fez parte da maçonaria, através da loja maçônica América, que bancou sua defesa na liberdade de 42 negros em Jundiaí, como aponta o historiador Rodrigo Trespach em sua Obra: Histórias não (ou mal) contadas: Revoltas, Golpes e Revoluções no Brasil, 2017, p. 118.

Sem dúvidas, Luiz Gama configurou-se na história do Brasil como um defensor dos direitos humanos, como nas palavras de Nelson Câmara, o "advogado dos escravos", nas de Elciene de Azevedo, "Orfeu de Carapinha", e nas de Sud Mennucci, o "precursor do abolicionismo no Brasil."

A história do poeta termina lastimavelmente por culpa da diabetes, e seu corpo foi sepultado em 25 de agosto de 1882. Seu cortejo contou com a presença de 3 mil pessoas, dentre elas, negros, como membros das lojas maçônicas, advogados, lentes, acadêmicos, magistrados, jornalistas, nas palavras de Raul Pompéia, "todas as classes representavam-se ali."

Luiz Gonzaga Pinto da Gama, lutou pela causa abolicionista sem ver sua concretização em 13 de maio de 1888 , não pudera ver seu sonho realizado e tão esforçadamente lutado, mas sem sombra de dúvidas, contribuiu para a sua consolidação na emocionante cena abolicionista da História brasileira. 


\section{REFERÊNCIAS:}

ANDERSON, Benedict. Comunidades Imaginadas: reflexões sobre a origem e a difusão do nacionalismo. São Paulo: Companhia das Letras. 2008.

AZEVEDO, Elciene, Orfeu de Carapinha: A trajetória de Luiz Gama na imperial cidade de São Paulo. $2^{\mathrm{a}}$. Reimpressão, Campinas, SP, Editora da Unicamp, 1999.

CÂMARA, Nelson. O Advogado dos Escravos: Luiz Gama. 2a . Ed. São Paulo, Ed. Lettera.doc, 2009.

CARVALHO, Gilberto de Abreu Sodré, 1947 - O Advogado e o Imperador: a história de um herói brasileiro. $1^{\mathrm{a}}$. Ed. São Paulo, Duna Dueto, 2015.

CUNHA, Maria de Fátima da. Mulher e historiografia: da visibilidade à diferença. His. Ensino, Londrina, v. p.6, 141161 , out, 2000.

FAUSTO, Boris. História Concisa do Brasil. $2^{\mathrm{a}}$. Ed. $6^{\mathrm{a}}$ Reimpressão, São Paulo, Ed. Da Universidade de São Paulo, 2014.

GAMA, Luiz. Carta de Luiz Gama à Lúcio de Mendonça, 25 de Jul. 1880, Biblioteca Nacional/Manuscritos: correspondência avulsa. Disponível em Sud Mennucci, O Precursor do Abolicionismo no Brasil. Luiz Gama. São Paulo, Nacional, 1938, p. 19-36.

Meus Amores, Diabo Coxo, 03 de Setembro de 1865. Disponível em AZEVEDO, Elciene. Orfeu de Carapinha: a trajetória de Luiz Gama na imperial cidade de São Paulo. Campinas, SP, Ed. Unicamp, 1999.

Publicação de Luiz Gama de 18 de

Novembro de 1869, Correio Paulistano, Edição 4025, São Paulo. Biblioteca Nacional. Disponível em: <http://www. bndigital.bn.br/acervo-digital/correio-paulistano/090972>. Acesso em: 27 novembro 2017.

Publicação de Luiz Gama de 20 de

Novembro de 1869, Correio Paulistano, Edição 4026, São Paulo. Biblioteca Nacional. Disponível em: <http://www. bndigital.bn.br/acervo-digital/correio-paulistano/090972>. Acesso em 27 novembro 2017.

Publicação de anúncio de Luiz Gama de 23

de Janeiro de 1870, Correio Paulistano, Edição 4074, São Paulo. Biblioteca Nacional. Disponível em: <http://www. bndigital.bn.br/acervo-digital/correio-paulistano/090972>. Acesso em 27 novembro 2017.

Trovas Burlescas. São Paulo. SESI-Editora, 2017

HOBSBAWN, Erick. Nações e Nacionalismo desde 1780: programa, mito e realidade. Rio de Janeiro: Paz e Terra, 1990

MENNUCCI, Sud, O Precursor do Abolicionismo no Brasil. Luiz Gama. São Paulo. Nacional, 1938.
NADAI, Elza. "O ensino de história no Brasil: trajetórias e perspectiva”. IN: Revista Brasileira de História. São Paulo. Vol. 13. N. 25 e 26, p. 1432-162, set.92/ago.93.

REIS, João José. Rebelião Escrava no Brasil: a história do levante dos Malês (1835). São Paulo: Companhia das letras, 2003.

SAVIANI, Dermeval. A nova lei de educação: trajetória, limites e perspectivas. Campinas: Autores Associados, 1997.

SILVA, Luiz, Luiz Gama: uma trajetória além de seu tempo. Estudos afro-asiáticos, n. 16, mar., 1989.

SCHWARCZ, Moritz Lilia: Nem preto, nem branco, muito pelo contrário: cor e raça na sociabilidade brasileira. $1^{\mathrm{a}}$. Edição, São Paulo, Claro enigma, 2012.

TRESPACH, Rodrigo. Histórias não ou (mal) contadas: Revoltas, Golpes e Revoluções no Brasil. $1^{\text {a }}$. Ed, Rio de Janeiro, Harper Colins, 2017. 